\title{
Luz Criativa - o legado de Appia e as cenografias intermidiáticas de Hotel Pro Forma
}

Creative Light - Appia's legacy and the intermidiatic scenography of Hotel Pro Forma

Birgit Wiens ${ }^{2}$

Tradução: Stephan Arnulf Baumgärtel ${ }^{3}$ 


\section{Resumo}

Essa contribuição discute o legado de Appia do ponto de vista dos estudos da imagem. Appia rejeitou a perspectiva linear como uma 'ilusão ótica' e desenvolveu uma concepção de visualidade na qual, pela primeira vez na história do teatro, a luz assegura que as imagens em cena viram um evento; em vez de apenas aparecer como imagens emolduradas, elas podem agora ser vistas como um enigmático e movimentado "trançado enredado" (Lacan). Concomitantemente, o publico é confrontado agora com a "perspectiva vivida da experiência" (Merleau-Ponty). Como exemplos, o artigo discute dois trabalhos do grupo Hotel Pro Forma, Operation: Orfeo (1993/2007) e Algebra of Place (2006), que reconectam com Appia na época da mídia eletrônica por usarem conceitos de imagem não lineares, como por exemplo, o palimpsesto ou a arabesque.

Palavras-chave: Iluminação cênica moderna; iluminação cênica contemporânea; configuração da percepção; interculturalidade.

\section{Abstract}

This contribution discusses Appia's legacy from a visual studies viewpoint. Appia rejected the linear perspective as an optical illusion and developed a concept of visuality whereby, for the first time in theatre history, light ensures that the stage images become an event; instead of just appearing as framed pictures they can now be viewed as moving, enigmatic 'interwoven wickerwork' (Lacan). This goes hand in hand with an audience that is now confronted with the 'experienced perspective (Merleau-Ponty). As examples, the article discusses two works of the artistic group Hotel Pro Forma, Operation: Orfeo (1993/2007) and Algebra of Place (2006), that reconnect with Appia in the age of electronic media by using non-linear image concepts, such as the palimpsest or arabesque.

Keywords: Modern stage lighting; contemporary stage lighting; configurations of perception; interculturalism.

ISSN: 1414.5731

E-ISSN: 2358.6958

\footnotetext{
1 Publicado originalmente em: Brandstetter, Gabriele e Wiens, Birgit (eds.) Theater ohne Fluchtpunkt. Das Erbe Adolphe Appias: Szenographie und Choreographie im zeitgenössischen Theater. Berlin: Alexander Verlag, 2010, p. 223-254.

2 Professora Dra. Habil no Departamento de Ciências Teatrais na Ludwing -Maximillians-University (LMU) de Monique, Alemanha.
}

3 Professor Dr. Associado da Universidade do Estado de Santa Catarina (UDESC), atuando junto ao Programa de Pós-Graduação em Teatro (PPGTCEART). stephao08@yahoo.com.br 


\section{Introdução: Hellerau como lugar e acontecimento de outro modo de ver}

Em suas reminiscências da experiência de ter assistido Orfeu no verão de 1912 em Hellerau, o romancista americano Upton Sinclair descreve o quão profundamente lhe impressionou essa apresentação. Em seu andamento - no jogo entre a luz fluída, atmosférica do espaço e os movimentos rítmicos dos atores-performers - se "trançavam desenhos que eram tão complexamente calculados quanto era a música [...] Imagens incrivelmente belas foram apresentadas a nosso olhar (Sinclair, 1940/2006, p.149). Uma série de outros comentários de espectadores daquela apresentação (que são conservados em cartas, ensaios e críticas) atestam que sobretudo as cenas de Orfeu que Adolphe Appia e Émile Jaques Dalcroze criaram, a partir da ópera de Gluck entre 1912 e 1913 (quando o trabalho inteiro estreou) - foram experimentadas não apenas como um acontecimento sonoro, senão decididamente visual; como encenação de uma forma inovadora de visualidade. Paul Claudel escreveu em uma carta a um amigo francês: "É uma fusão de música, senso plástico e luz como nunca antes experimentei. As telas pintadas, os adereços, toda a gravidade ridícula do teatro antigo, são varridos [da cena]" (citado em Beacham, 2006, p.152f).

Aqui se articulou obviamente um tipo de público que se interessou por seu próprio olhar. Dessa maneira expressa-se claramente um desconforto em relação ao caduco palco ilusionista enquanto uma forma profundamente marcada por procedimentos da perspectiva central. Trata-se de uma crítica que estava no ar: Apesar da longa história de sucesso dessa perspectiva, há tempo tinha se iniciado em outros âmbitos culturais uma crítica desse procedimento de produção de imagens. Se negava a posição de ser uma técnica universal e um modelo de validade global. Friedrich Nietzsche, por exemplo, perguntou, até onde chegaria "o caráter perspectivista da existência" e julgou uma "falta de humildade ridículo, decretar que apenas a partir do próprio cantinho se possa possuir uma perspectiva" (Nietzsche, 1882/2000, p.286).

A crítica filosófica não estava sozinha neste questionamento das reivindicações ocidentais de possuir a visão do mundo "correta". Também em outros campos tornou-se patente, como disse Nietzsche, "uma curiosidade desesperada de querer saber que modos de intelecto e perspectiva ainda poderiam existir" (Nietzsche, 1882/2000, p.286). Aconteceu uma virada de olhar, uma transformação profunda da percepção e do ver: a imagem da perspectiva central foi reconhecida como uma representação da coisa e do mundo que baseava-se em uma abstração geométrica e era adaptada para um olho descorporificado e um observador fixado. Do final do século XIX, do ponto de vista de um observador que agora vivia em movimento, essa estrutura não parecia ser mais apropriada aos tempos contemporâneos. Com os olhos, o espírito e os sentidos começaram uma busca por "outros modos de intelecto e perspectiva". Podemos denominar esse novo interesse por tudo que a imagem perspectivada não representava, junto com Foucault, como tentativa de "pensar o fora" (Foucault, 1986, sobretudo p. 13-25). Abriu um modo de perceber que interroga não só as imagens (no sentido de representações), mas sobretudo as modalidades de seu ato de apresentar-se. Com isso, entrou no jogo a questão do que está contido como invisível na dimensão visível das imagens, como também a questão do observador, de sua percepção e de seu olhar. 
Quando Appia (1899/2006, p.81 e 92), em seus textos teóricos sobre o teatro, descarta a "ilusão ótica" da decoração pintada e, contra essa, afirma como objetivo possibilitar um "novo modo de perceber" no sentido de um olhar ativo, ele o faz nesse contexto esboçado. Por conseguinte, o teatro de Appia se depara com a interrogação da imagem, ou - para usar um termo introduzido por Gottfried Boehm - a questão acerca de suas qualidades enquanto uma "configuração de visibilidades no contexto de uma história do olhar (Boehm, 2006, p.17). Até agora, os estudo teatrais se ocuparam relativamente pouco com tais questões em relação a uma cenografia moderna e outra contemporânea. Ainda que aborde o trabalho de Appia comumente sob o termo "cenografia" e o relacione com os inícios de uma cenografia moderna (ver Pavis, 1996, p. 314-317), essa abordagem, sobretudo no contexto de um uso tradicional do termo, não é sem problemas. É sabido que na antiguidade grega entendeu-se sob skênographia uma arte de decorar a skene (a fachada frontal do edifício cênico) com uma decoração pictórica. No século XVI, iguala-se o termo "cenografia" à recém inventada perspectiva (Rosenfeld, 2003, p.292f), como se pode perceber nos tratados sobre arquitetura de Sebastiano Serlios. Visto assim, cenografia é um discurso de imagens.

A história da cenografia moderna, entretanto, inicia-se com um iconoclasmo: $O$ palco caduco da perspectiva central está descartado em favor do palco espacial aberto. Esse gesto iconoclástico serviu aos estudos teatrais - que se institucionalizaram na mesma época - como justificativa para criar a tese (até hoje ativa) de que há uma estranheza fundamental entre imagem e teatro ou entre experiência espacial e outra pictórica (Hermann, 1931/2006), p.510). Nesse sentido, o discurso acerca da cenografia mais recente se formou, como apontou Christopher Balme, enquanto "discurso antipictórico". No entanto, aqui faz-se necessário uma revisão. Mesmo que Appia e seus aliados amplamente abrissem mão de decorações pintadas, esse fato não indicou um pensamento antipictórico, como bem enfatiza Balme. Seria mais correto dizer - e na época testemunhas relataram isso com toda fascinação - que de certa maneira pintou-se por cima de uma concepção pictórica mais antiga, agora em crise. No lugar desta estabeleceu-se uma concepção performativa que juntou em forma de "módulos cênicos" (Buber, 1913/1991, p.433) elementos cênicos móveis, movimentos rítmicos no espaço e sobretudo um uso inovador e decididamente artístico da iluminação, o que Martin Buber chamou de "luz criadora". O que aconteceu foi uma transformação das concepções caducas da representação pictórica em uma visualidade dinâmica, composta em forma de módulos e que visava ampliar o espaço. Ou, em outras palavras, criou-se uma nova compreensão do pictórico.

Sob o fundamento do que foi dito até agora, essa ensaio intenta duas coisas. Primeiramente, trata-se de precisar o conceito da cenografia moderna, como foi aberta por Appia, com uma teoria da imagem. Buscarei um conceito pictórico que permite descrever imagens como "espaços pictóricos" dinâmicos; como trançado multi-dimensional de grafismos, de intensidades, de contrastes, de luz e distâncias, que torna algo visível. Essas reflexões estão ligadas à teoria da imagem e do olhar de Jacques Lacan, sobretudo pensar o sentido da luz, que aqui serve como força movente. A partir disso, a segunda parte aborda uma prática de cenografia contemporânea. Apresentase o trabalho do grupo dinamarquês Hotel Pro Forma, que referencia os procedimentos appianos de cenografia e tratamento da luz e que os reformula nas condições das 
imagens na época das mídias eletrônicas e da globalização. Pretendo mostrar como, em variações sempre novas e não mais limitados [apenas] ao campo cultural ocidental, os projetos teatrais e instalações performativas desse grupo de artistas tratam daquilo que Appia em seu tempo chamou a exploração de "novas maneiras de olhar".

\section{1. “O que é luz, me olha. Cenografia moderna, a transformação da concepção de imagem e a (re-)descoberta da luz}

No final do século XIX, busca-se, para falar mais uma vez com Nietzsche, olhar para o mundo não mais a partir de apenas uma perspectiva. Sobretudo nas artes visuais realiza-se várias tentativas de deixar para trás essas "compulsões visuais", por meio de uma exploração da multi-perspectividade do realismo ou por sua redução a formas elementares bem como à abstração. Aquilo que Foucault analisou como escritura e ordem do espaço pictórico, entra em crise e até está sendo negada: "[...] como isso desaparece aquela camada uniforme na qual se cruzaram o visto e o lido, o visível e o dizível. [...] O olho será destinado a ver e apenas a ver" (Foucault, 1966/1989, p.75). Esses deslocamentos não aconteceram sem irritações, como fica patente na obra de Cézanne que não se cansou na tentativa de eliminar a "janela", ou seja a imagem de uma projeção imaginária criada pela perspectiva geométrica, e de investigar os dados sensoriais de seu campo visual e de presentificá-las enquanto "perspectiva vivenciada". Cheio de dúvidas, e apesar da crescente manifestação de um sucesso artístico, Cézanne desconfiou que sofresse de um transtorno visual. Mais tarde, suas experiências se tornaram objeto das análises de Merleau-Ponty do olhar humano, em seu caminho para um conceito fenomenológico da imagem (Merleau-Ponty, 2006, p.39-59).

Uma das especificadas presentes nas pinturas de Cézanne é o tratamento da luz, como bem frisa Merleau-Ponty. A luta pela "perspectiva vivenciada" levou Cézanne a questões sobre a ótica. A investigação das coisas percebidas no campo visual não devia seguir à impressão, mas a um "olhar lógico"; a uma ótica ainda por "ser criada" (Merleau -Ponty, 2006, p.44). Cézanne chegou a modulações de luz e cor que lhe possibilitaram mostrar a matéria "como ela está prestes a se dar uma forma" e conferi-la qualidades táteis e atmosferas. Seus espaços pictóricos, que não são espaços geométricos, estão vibrando; neles, a luz produz efeitos de evocar a forma como se ela fosse uma força criadora, nos quais ela mesma como "irradiação que vem de lugar algum" não revela sua procedência (Merleau-Ponty, 2006, p.59).

\section{1 "Brilhar de lugar algum". Comentários sobre a luz de Hellerau}

$\mathrm{O}$ que confere à imagem que se desdobra cotidianamente perante o nosso olhar sua grandiosa unidade, que faz com que vivamos por meio do olho? A luz! Sem essa potência que cria unidade nossos olhos poderiam muito bem compreender o 'significado' das coisas, mas nunca sua 'expressividade' [...] (Adolphe Appia).

As características do espaço pictórico dinâmico e o novo entendimento da luz 
concomitante a este certamente eram conhecidos pelos artistas de Hellerau e por seu público a partir das artes visuais. Entretanto, é outra coisa ainda, realizar e vivenciar tal princípio pictórico nesta outra mídia que é o teatro. A invenção da luz elétrica e suas condições técnicas específicas contribuíram para que fosse atribuído à luz também esteticamente um papel chave. Agora, a luz é nomeada um co-ator em cena: "A luz precisa tornar-se ativa, igual ao ator", escreve Appia. ${ }^{4}$ Em seus esboços teóricos, distingue entre dois tipos de luz: a "luz distribuída" que causa uma claridade geral e - mais importante do que essa - a "luz formadora" (Appia, 1899/2006, p.98). Appia confere "expressividade" à luz. Para que ela, mesmo sendo invisível, possa desenvolver esse potencial, necessita de "obstáculos" - não painéis pintados, mas corpos e objetos, no sentido de componentes; módulos móveis com quais a luz pode realizar algo como sua escrita: ceno-grafia. A luz não apenas ilumina esses componentes e os torna visíveis, mas sempre as modela também em vários sentidos: por conferir-lhes plasticidade; fazer com que se realce a sensualidade de sua materialidade e de seus contornos e os mergulha em uma "atmosfera" "que lhes convém" (Appia, 1899/2006, p.94-95). Conforme essa concepção, luz e espaço estão em uma relação mútua.

Os estudos teatrais descreveram a fundo as condições arquitetônicas e mediais criadas por Appia para esse fim: a sala aberta do teatro concebido por Heinrich Tessenow e o sistema de iluminação elétrico, desenvolvido por Alexander von Salzmann e altamente inovador em sua época, que escondeu milhares de lâmpadas e refletores atrás de grandes painéis brancos semitransparentes e que possuía refletores giráveis. Os espaços que Appia desenhou e realizou com esses meios eram acontecimentos, ou - para usar o termo usual dos estudos teatrais - espaços performativos. Em consonância com isso, Appia os concebeu não como algo ficcional no sentido de um "cenário", mas, igual à luz, como algo "factual, [...] plástico" (Appia, 1899/2006, p.129). Sua alta performatividade específica, entretanto, não os libera de suas qualidades pictóricas. Antes, é preciso determiná-las melhor.

Sinclair escreve que "imagens maravilhosas [...] foram oferecidas ao olho" e Martin Buber relata como nas alterações da luz se transformava a materialidade das coisas e surgia uma "imagem do espaço" mudada. Esses depoimentos sugerem, então, que a imagem se abriu sobretudo por meio de percepções sensoriais, ou seja, por meio de uma maneira específica de olhar. Para defini-la melhor devemos notar em primeiro lugar que com esse palco trata-se também de um dispositivo visual, uma estrutura para organizar o olhar - um fato que nem sempre recebe sua devida atenção no discurso sobre o palco espacialmente aberto. Buber a descreve da seguinte maneira:

Arquitetonicamente, a sala toda é uma unidade; o palco não é separado do público - que não fica no escuro separador, mas na luz comum - por meio de sua construção, mas unicamente por aquilo em que ele está sendo transformado: o palco não é outra coisa do que lhe acontece. Entretanto, tudo que lhe acontece é organizado internamente de modo rigoroso e claro; separado de nos de modo

4 Essa citação encontra-se em seu texto de 1921, e publicado postumamente em 1954, Darsteller, Raum, Licht, Malerei [ator, espaço, luz, pintura], p. 439. O texto Die Musik und die Inszenierung [A música e a encenação] de 1899 também já contém considerações semelhantes acerca do papel da luz. 
rigoroso e claro pelo jeito como acontece (Buber, 1913/1991, p.432).

A inovação central desse novo espaço teatral consistia, como sabemos, na renuncia à boca de cena, ao proscênio e a enquadramentos parecidos. Apenas o uso de uma cortina - aliás contra a vontade de Appia - é confirmada para a apresentação do Orfeu de 1913 (ver Beacham, 2006, p.144). Também abriu-se mão do escurecimento do espaço da plateia, diferente do que praticado em Bayreuth. Os dois espaços, palco e plateia, foram ligados, portanto, não apenas pelas emanações dos sons que se difundiam, mas também pelas emanações da luz formadora, ou da luz produtiva, "criadora" nas palavras de Buber. Entretanto, havia, como ressalta também Buber, uma fronteira estética entre ambos os espaços que foi criado como algo "rigoroso e claro", entretanto unicamente de modo performativo (Beacham, 2006, p.144). Se a imagem do palco, na maneira como descrita, é liberado de sua moldura, põe-se a questão onde e de que maneira a imagem e sua qualidade pictórica aparecem, se tornam visível. Há bastante evidência de que essas imagens são tão efémeras quanto a luz que as cria e pela qual elas surgem; além disso, elas se estendem ao espaço e não são mais dependentes da correlação entre olho e pontos de fuga. Dessa maneira, de fato torna-se possível uma outra "maneira de olhar"; um olhar que está mais dado e distanciado por uma estática construtiva e uma abstração técnica, mas que adquire uma qualidade processual, por ser (novamente) ligada com o corpo dos espectadores e os olhos daqueles que veem. O corpo [como soma], diz Merleau-Ponty (1994, p.182), "está contido no grande espetáculo".

Ora, a luz possui, com comenta Appia (1954/1991, p.439), a característica "que beira o milagroso, de difundir suas vibrações no espaço", ou seja, de movimentar-se de modo multidirecional pelo espaço que ela concomitantemente cria como algo visível. Entretanto, a percepção visual humana não corresponde a essa multidirecionalidade e polipontuação dinâmica. Ela depende do corpo humano, dos olhos e do campo de visão: pode-se ver o que surge nesse campo de visão e o aparelho perceptivo humano o transforma em imagem.

\section{2 "Coreografia para o olho". Danças de luz e superfícies que escorrem}

É preciso criar uma ótica para si mesmo [...]. Sob ótica, entendo um ver lógico. Ou seja, não algo que vai contra a razão.

(Paul Cezanne)

Como disse, as reflexões de Appia sobre uma nova "maneira de olhar" no teatro se fundamentaram em boa parte em reflexões sistemáticas acerca da performatividade da luz. Renunciando a construção bidimensional e estática da imagem da perspectiva central, ele estava interessado em configurar a significação da imagem enquanto processo - como acontecimento estético no qual visualidade chegará a ser exibida de modo extensivo e dinâmico nas mudanças dos efeitos da luz e se desdobrará no olho de um observador que percebe ativamente. O surgimento da fotografia também deve- 
ria contribuído naquela época para o desejo subjacente de explorar "outras formas de perspectiva". Ela parecia objetivar a imagem da perspectiva central de modo praticamente habitual e irreversível. A necessidade de contrapor a essas imagens outras configurações, sobretudo aquelas de uma "perspectiva vivenciada", levou muitos artistas daquela época a ocupar-se de questões da ótica. Uma das questões foi especialmente debatida, em que sentido a "imagem vista" - como imagem em cuja formação a consciência e a percepção corpórea participam - se diferencia da chamada "imagem da retina" (uma diferença que o pensamento da perspectiva central negligencia).

"Eu não sou simplesmente aquele ser em forma de ponto que se poderia fixar em qualquer ponto da geometria do qual a perspectiva deveria partir", escreveu nesse sentido mais tarde Lacan (cit. em Boehm, 2006, p.65), que desenvolveu um modelo teórico acerca da relação imagem e percepção que mais uma vez atribuiu à luz funções ativas.

O modelo de Lacan se apoia em primeiro lugar nas premissas fenomenológicas de Merleau-Ponty. Este formulou em sua obra tardia (e, como já dito antes, também em diálogo crítico com a arte de Cézanne) sua teoria do processo perceptivo humano que ele interpretou como um jogo que altera ver e ser visto. Desse modo, Merleau-Ponty tirou o sujeito que vê de sua posição frente à realidade e o colocou no meio do mundo, ao interpretá-lo como um ser de dupla face, que olha e sempre está sendo olhado (Merleau-Ponty, 1994, p.180). Lacan parte dessa teoria e the dá um prosseguimento psicanalítico. O processo de ver e a constituição da imagem acontecem, segundo ele, em um cruzamento dos olhares: O impulso do ver, o desejo de ver que parte do sujeito, se cruza com o ato de ser visto, que transforma o próprio sujeito em objeto, em um "tableau". Esse campo tenso Lacan interpreta junto com Merleau-Ponty como um "trançado": como campo no qual ver e ser visto se desenrola como um soltar de fio de luz. Ele frisa explicitamente a dinâmica desse jogo alternado ao pressupor "uma relação natural entre olhar e luz"; visibilidade surge, conforme Lacan, naquele momento quando os fio da luz, respectivamente do olhar, passam por uma "rede em forma de uma tela na qual identificamos o quadro/a imagem (cit. em Boehm, 2006, p.62). “O que é luz, me olha", escreve Lacan; aquilo que se torna visível, mostra-se como "o escorrer de uma superfície", como configuração cintilante de visibilidade com margens desfiadas. Uma configuração que não está de antemão - como a imagem tradicional "estruturada para afirmar a distância" (cit. em Boehm, 2006, p.65). Diferente do espaço geométrico da ótica, as configurações do ver fenomenológico não são transparentes, segundo Lacan. Antes, aquilo que ele chama de "tela", é opaco e o "espetáculo" que se tornar visível sobre ele é um "jogo entre luz e opacidade" (cit. em Boehm, 2006, p.65).

Há muitos indícios de que aquela "configuração de visibilidade, dentro da qual Appia e Jaques Dalcroze encenaram a busca do Orfeu apaixonado por sua falecida Eurídice, corresponde a esta configuração imagética descrita por Lacan em seu modelo da imagem que é sobretudo um modelo de olhares. Mais tarde se comentou sobre Appia que ele foi um dos primeiros a desenvolver na história teatral europeia uma 'linguagem teatral' que aparece em sua transposição para a cena como "coreografia para olho" (Linders, 2006, p.10), como formulou Robert Wilson, que possui uma afinidade eletiva com Appia. Estudos acerca da imagem mais recentes mostraram que a crise da linguagem e da escrita daquela época, que destina o olho "para ver e apenas para ver" (Foucault), levou a uma volta das imagens. No início do século XXI, essa problemáti- 
ca se coloca mais uma vez, mas de uma maneira nova: dando sequência à chamada "primeira virada midiática" (a invenção de mídia analógica como fotografia e filme), a "segunda virada midiática" (o surgimento das mídias digitais e de uma comunicação em rede global) faz como que a problemática das imagem se torna visível literalmente sob uma luz diferente. Disso resulta de fato uma "percepção atenta da imagem" que levanta - tanto do ponto de vista teórico quanto artístico - uma série de questões acerca da lógica de imagens e de novas abordagens analíticas das culturas da imagem. Não se trata simplesmente de colocar de modo renovado e diferente "a questão sobre a imagem e o tratamento da imagem", mas fundamentalmente de "relacioná-la com a questão acerca da compreensão das culturas ocidentais de si mesmas" (Röttger/Alexander, 2009 , p.31). No que segue, queremos mostrar nos trabalhos exemplares do grupo dinamarquês Hotel Pro Forma que essa questão ultrapassou a modernidade teatral e se tornou uma problemática importante e desafiadora da cenografia mais recente.

\section{Após Appia. As cenografias de Hotel Pro Forma}

O mundo e a visão do mundo mudam. Portanto, a arte tem que fazer igual [...]!"” (Per Theil)

Normalmente se classifica nos estudos teatrais projetos como aqueles que Hotel Pro Forma apresenta, desde os meados dos anos 1980 em festivais internacionais, com termos tais como "teatro das imagens" ou "teatro da cenografia" pós-dramática: uma arte teatral que opera sobretudo de modo visual e que vira as costas tanto ao textocentrismo e à narrativa linear quanto ao realismo psicológico e sua convenções correspondentes de um palco italiano (Lehmann, 2005, p.159). Principalmente nos anos iniciais de seu trabalho, chamou-se a Kirsten Dehlholm, a diretora artística de Hotel Pro Forma, o "gêmeo dinamarquês" do diretor americano Robert Wilson, artista da luz e da cena. Diferente de Wilson, entretanto, Dehlholm abre mão de um espaço fixo. Mais do que isso, para cada um de seus projetos de teatro, performance e instalação performativa ela busca propositalmente novas e diferentes situações espaciais (e logo também fora do contexto teatral). Portanto, o nome do grupo de artistas, Hotel Pro Forma, alude a um teatro que se compreende como "nômade", ou seja, um teatro que está sempre em viagem, também no que diz respeito a suas formas e a seus meios. Este tipo de trabalho se iguala a uma pesquisa básica. De modo verdadeiramente sistemático explora-se problemáticas da correlação espaço-imagem e potenciais que se abrem sob as condições das mídias eletrônicas, digitalizações e de uma comunicação em rede global. Em alguns trabalhos, o grupo ultrapassa a tradição cenográfica europeia ao examinar as concepções imagéticas de outras culturas como a asiática ou a árabe, levando assim à sério a indagação de Nietzsche em relação a outras perspectivas possíveis. O lema "Performance as investigation of the world/ Performance como investigação do mundo" serve com programa (cf. Theil et al., 2003, p.99). Como trabalhos exemplares, quero apresentar duas produções. A primeira, Hotel Pro Forma, Operation: Orfeu de 1993 e retomada em 2007 se propõe a realizar, como pretendo mostrar, uma revisão da tradição cenográfica europeia a partir de Appia. Algo que se aplica também à produção Algebra of Place (2006), que para além dessa questão inicia um diálogo e 
uma mudança de perspectiva entre duas culturas, nesse caso entre oriente e ocidente.

\subsection{Cenografia enquanto palimpsesto. Sobre a organização de espaço e olhada em Operation: Orfeo}

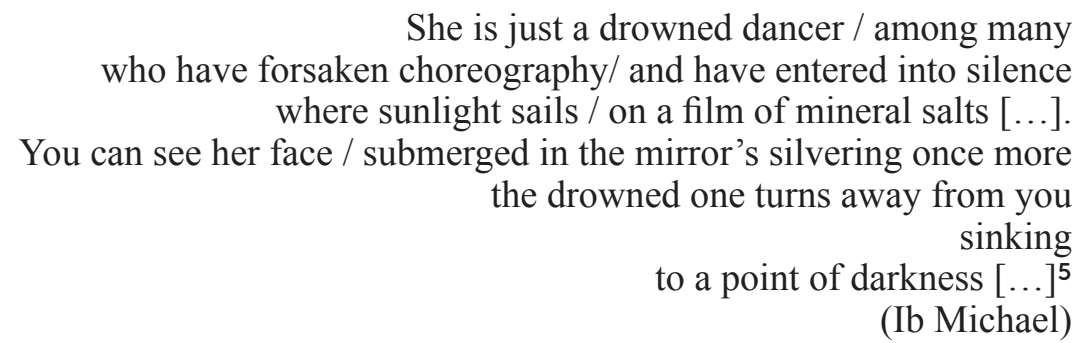

Operation: Orfeo é uma variação sobre a temática de Orfeu. Como já indica o título, o espectador não pode esperar uma apresentação convencional completa da ópera de Monteverdi ou de Gluck. Mesmo que a variação de Orfeu concebida por Dehlholm seja a única produção de Hotel Pro Forma em grande escala feita para um palco italiano - em sua concepção visual, ela é uma "opera visual em três movimentos" - esse palco sofre em Operation: Orfeo uma redefinição resoluta. Como vai se tornar claro, a apresentação pode ser descrita mais adequada como uma textura visual e musical que se dá a conhecer em uma recursividade específica a outras obras, apresentações e mídias. Essa concepção especial como "textura" concerne, por um lado, a dimensão musical: a maior parte das composição - apresentadas completamente "a capella" por um conjunto de vocalistas e uma solista - são composições de autoria de John Cage e Bo Holten, alternadamente apresentadas com um libreto de Ib Michael. Apenas em um momento dessa encenação de aproximadamente 80 minutos, pode-se ouvir uma ária da ópera Orfeu e Eurídice de Gluck. Entretanto, é sobretudo a dimensão visual desse encenação que se apresenta como uma textura fluida em constante transformação. A cena, concebida por Maja Ravn, junto com a concepção bastante elaborada de iluminação de Jesper Kongshaug, claramente presta homenagem às escadas e formas básicas abstratas de Appia e sobretudo à sua "luz criativa" para modular plasticidade e atmosfera. Entretanto, se o acontecimento cênico de Appia se deu como dança dos corpos e dos elementos dinamizados num espaço aberto, emoldurado apenas pelas delimitações do espaço cênico de pelo "modo como aconteceu" (Buber), Dehlholm, Ravn e Kongshaug o transportam em sua versão para a superfície plana. Operation: Orfeo é encenada como uma operação visual que faz com que a busca de Orfeu por Eurídice passa em uma superfície visual dinâmica enquanto o processo de um movimento da esfera dos vivos para a dos mortos; enquanto duplo de luz e sombra, de claridade e escuridão. A superfície visual se torna o espaço de uma passagem, a suposta superfície visual vira uma soleira na qual acontece a história de Orfeu e Eurídice numa corrente de imagens mutantes. Poderíamos chamar essa narrativa "uma coreografia para o olho".

5 Ela é apenas uma dançarina afogada/ entre muitos que abriram mão da coreografia/ e enterraram em silêncio onde veleja a luz do sol/ sobre um filme

mais uma vez/ a afogada vira as costas para você/ afundando para um ponto de sais minerais [...]. Você pode ver seu rosto/ imerso na prateação do espelho de escuridão. 
O que se narra não é, como frisa Kirsten Dehlhom (2003, p.118), "uma estória, mas precisamente um movimento".

Este movimento, no limiar entre vida e morte, entre o visível e o invisível, se realiza em três fases: 1. Darkness-Descent [escuridão-descida], descida para o mundo dos mortos e a busca por Eurídice, 2. Clair Obscur - Ascent [claridade obscura - ascensão], o caminho de volta pelo mundo das sombras e 3. Light-Remembrance [luz-recordação], o reconhecimento da (nova) perda e o início da recordação. Na primeira fase, no início da busca, a cena, que se transformará em um espaço de passagem, é enquadrada por uma moldura luzente.

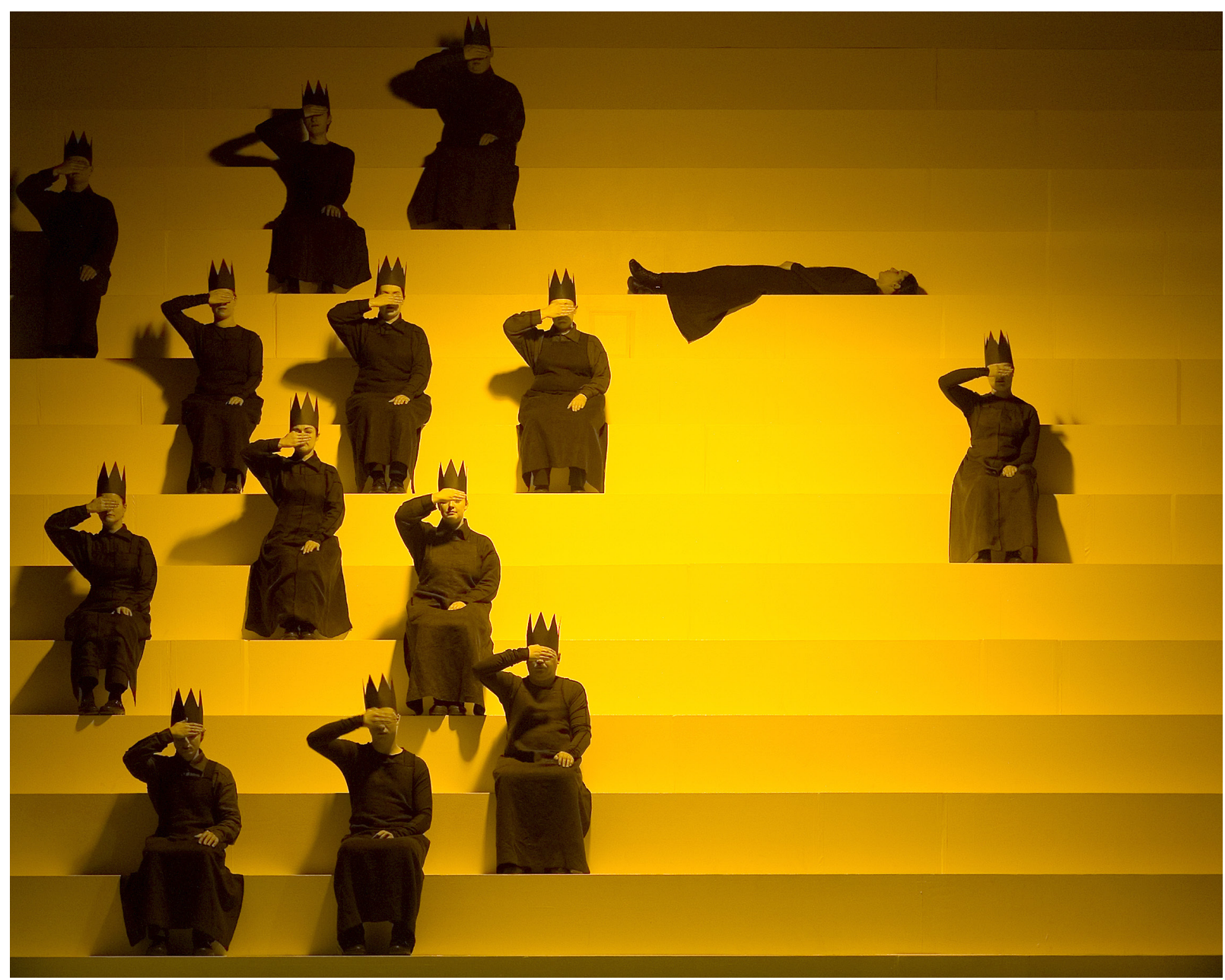

Imagem 1 - Cena de: Operation - Orfeo 


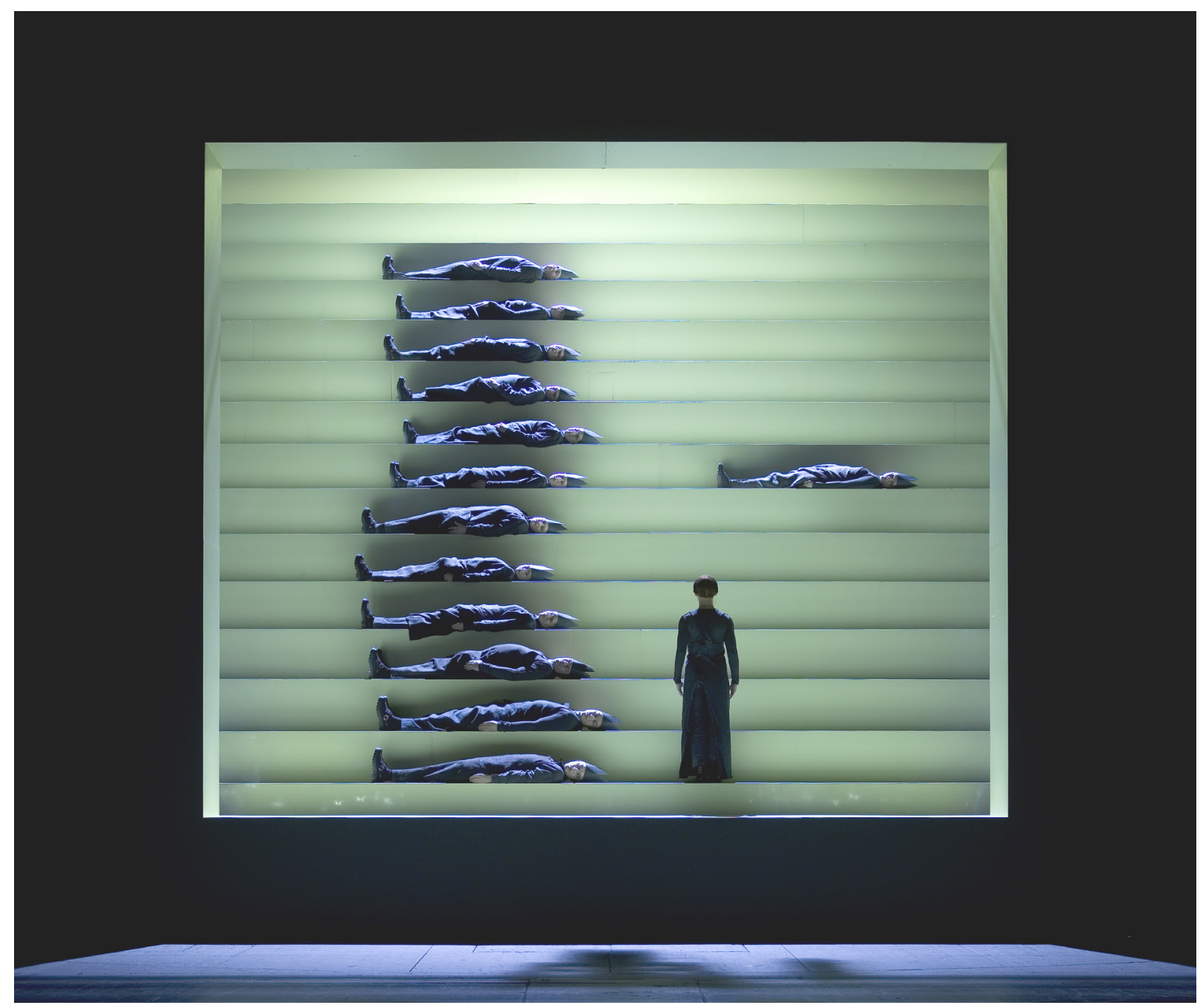

Imagem 2 - Cena de Operation: Orfeo

O coro de 13 cantores e de uma bailarina se agrupa em formações mutantes sobre os íngremes degraus de uma escada que parece subir até o infinito. Todas as figuras vestem o mesmo figurino, de azul escuro sem características de gênero. Coro e bailarina mal podem ser diferenciados também pelo modo de sua atuação. Cada um é Orfeu e cada um é Eurídice. Seus movimentos são altamente formalizados. As constelações e colocações mutantes se inscrevem no campo da visão que nem grafismos, enquanto desenhos e signos pictóricos, que instantaneamente são sobrepostos no próximo momento; às vezes, figuras parecem até sumir, como num mimetismo, apenas para reaparecer e tornar-se visível novamente de modo diferente.

A luz assume nesse contexto diversas funções. Como comentado, ela marca a "tela" inicialmente por meio de uma moldura luzente - uma delimitação que logo desvanece após as cenas iniciais para abrir a configuração lateralmente. Por causa disso, se torna uma "tela" no sentido de Lacan, sobre a qual a imagem aparenta um acontecimento luzente e móvel por meio do jogo interativo entre figuras, coisas, oscilações da luz e o olhar do observador. Ademais, a performatividade da luz contribui para uma modelagem interna dessa "configuração visual trançada" no momento do aparecer e 
a seu constante fluxo. Assim, a luz cria, através de seu espectro de cores, diferentes atmosferas e amplitudes afetivas. Intensidades alternadas de claro e escuro evocam a impressão de distância e profundidade; num momento, fazem com que a imagem aparente abrir-se infinitamente para o fundo, para logo dar-lhe uma qualidade plana e bidimensional: um truque ótico. É um jogo frágil entre visibilidade e invisibilidade, presença e ausência, que faz aparecer (e desaparecer) figuras e configurações sobre essa superfície de aparência opaca. Como disse, conta-se um movimento e não uma história. Além disso, esse fluxo de signos visuais, gestos, efeitos de iluminação e sons se mantém deliberadamente ambíguo, uma vez que esses elementos são coordenados, mas não relacionados um ao outro: "coordenado, mas não sincronizado", diz uma anotação de Dahlholm (2003, p.118).

Essa sequência de imagens que se assemelha a uma evocação - ou melhor, a uma chamada de algo ou alguém ausente (a Eurídice morta) não apenas por meio da música, mas sobretudo por um querer-ver, por olhares (um procedimento que a saga de Orfeu no fundo proíbe) -, culmina perto do final da apresentação na experiência de uma perda de imagens. Há um momento em que as imagens saem da "tela": quando de repente uma luz verde de laser brilha até as últimas fileiras do espaço da plateia, como se envolvesse os sentados mergulhando-as em uma superfície de luz ondulante.

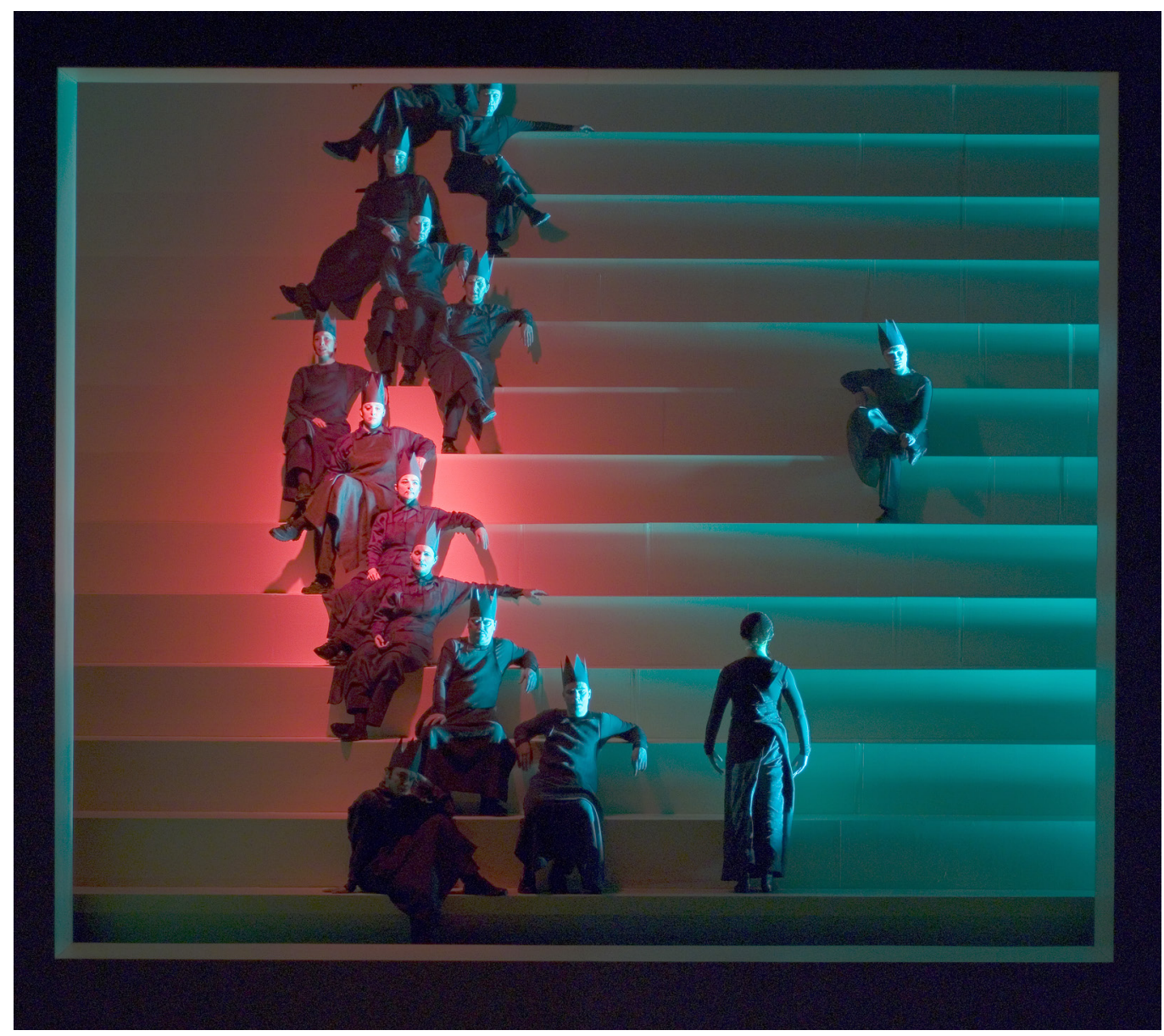

Imagem 3 - Cena de Operation: Orfeo 


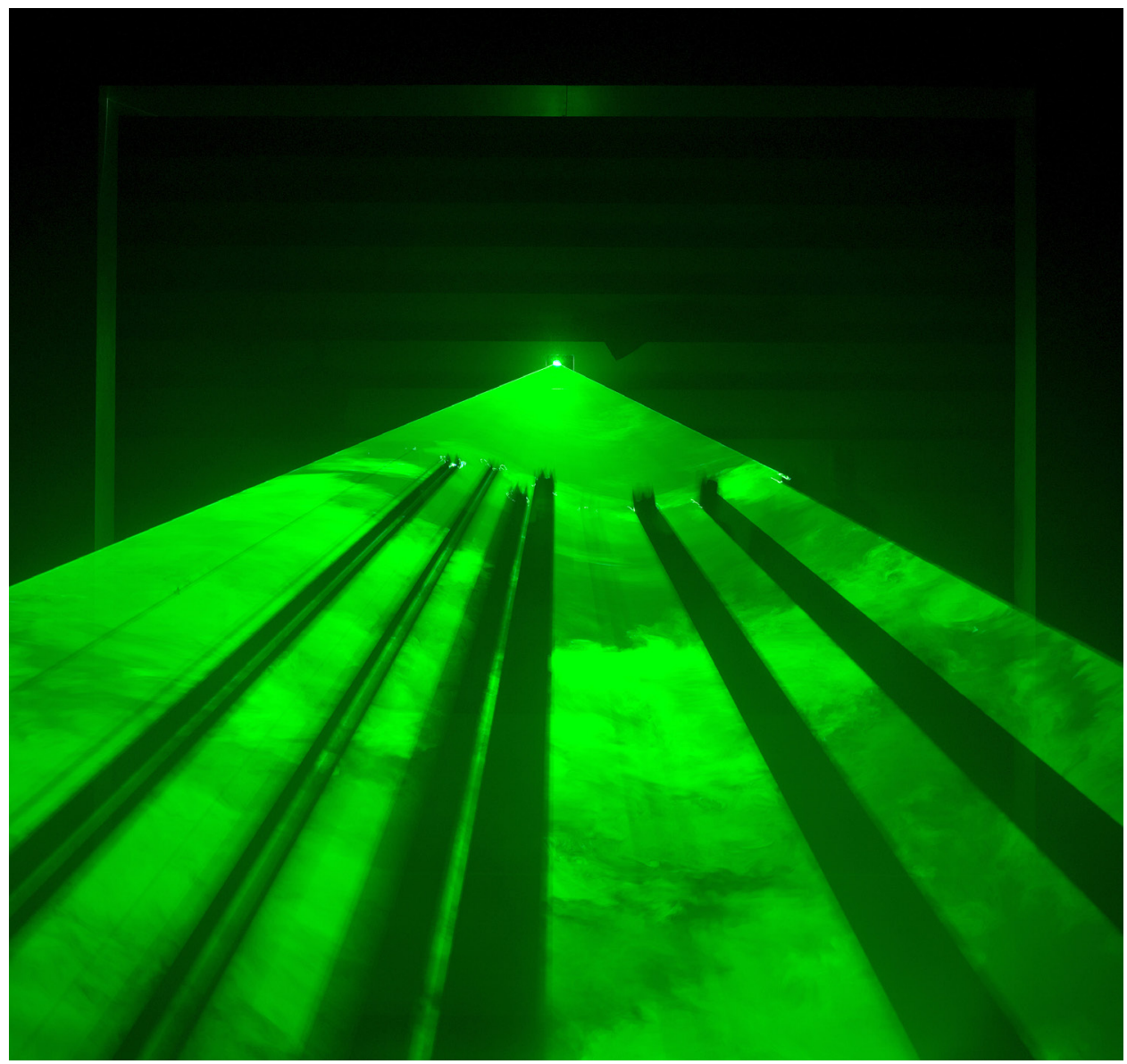

Imagem 4 - Cena de Operation: Orfeo

O que resta desse momento é apenas neblina, as figuras que agora se posicionam de costas para o público, e o próprio público. O que resta, então, é lembrança.

"[...] eterno esse morrer é/ pesado de olhos e mudez/ seu corpo uma pedra/ atirada atrás da imagem dela/ quando os círculos alcançam a extrema argola]6" (Michael, 1993, p.2), diz um trecho do libretto. De fato, não é somente a luz que em seu jogo com os elementos físicos faz brotar as imagens como movimentos ondulados. Antes, são sobretudo a percepção dos observadores, seu desejo de ver e os olhares "lançados" e emitidos por eles que as criam - como imagens que aparentam traços vagos sobre uma superfície brilhante "Onde a luz solar veleja/ sobre um filme de sais minerais"7 (Michael, 1993, p.5). Poder-se-ia dizer que aqui as imagens perderam quase completamente sua função representacional - ou, para falar com Foucault, sua escritura: "a obra não possui um sentido, sem que isso necessariamente implique que a obra seja sem sentido"8, escrevia o crítico teatral Per Theil sobre Operation: Orfeo. A visualidade que se apresenta aqui é outra - uma que se oferece não como representação, mas como um processo que acontece simultaneamente enquanto apresentação e insinuação, enquanto projeção e imaginação. Para especificar esse tipo de visibilidade teoricamente, o pesquisa- 
dor Klaus Krüger propôs em referência a Roland Barthes o conceito do "palimpsesto" (Krüger, 2007, sobretudo p.137f). Originalmente, o conceito se referia a uma superfície visual (como o papiro ou o pergaminho) que foi reutilizada e sobrescrita várias vezes. Krüger o interpreta como modelo do pensamento e da visualidade que compreende a significação visual "como acontecimento estético que se desdobra dinamicamente por recalque, troca e sobreposições, em explícita renúncia de uma concepção visual determinada estaticamente (Krüger, 2007, p.139). O conceito, tal como Krüger o propõe, visa descrever visualidade menos enquanto uma estrutura material, senão sobretudo como uma estrutura medial, na qual coexistem percepções heterogêneas, referências, relações de sentido e vários tipos de imaginação (Krüger, 2007, p.137). A produção Operation: Orfeo corresponde - eis uma de nossas teses aqui - em sua cenografia (que é sempre ao mesmo tempo uma coreografia) com o modelo do palimpsesto. A variação de Dehlholm do material Orfeu constrói referências não apenas de outras montagens anteriores (explicitamente a de Appia em Hellerau), mas reformula, como descrevemos, seu vocabulário formal e sua estética de impactos sob as condições visuais das mídias digitais. O palimpsesto, compreendido como um procedimento visual, devia ser avaliado como um modelo para a cenografia teatral contemporânea. Até que ponto esse modelo é apenas um entre outros, queremos investigar no que segue com mais alguns exemplos.

\subsection{Cenografia enquanto arabesco. A encenação de uma troca de olhares en- tre ocidente e oriente: Algebra of Place}

Um discurso sobre cenografia que não apenas investiga as imagens, mas interroga sobretudo as modalidades e condições culturalmente específicas de seu aparecimento - assim poderia ser caracterizado o trabalho de Hotel Pro Forma, que Kirsten Dehlholm também denomina de "pesquisa". "The performance starts with the space, the place" [A performance começa com o espaço, o lugar] (Dehlholm, 2003, p.99). Cada trabalho responde às condições do lugar de sua criação: a história e o contexto geográfico e urbano dele; à visualidade inscrita na arquitetura; as possibilidades de movimentação e organização dos olhares. Isso se aplica de modo específico ao projeto Algebra of Place que foi realizado, diferente do trabalho Operação: Orfeu, não como apresentação em um palco italiano, mas enquanto instalação performativa. Apesar de suas concepções artísticas distintas, ambos os trabalhos compartilham uma tentativa artística de realizar o que Foucault denominou "o pensamento do fora". Em outras palavras, ambos representam a tentativa de criar configurações cenográficas que presentificam o que a cultura ocidental da imagem não consegue representar enquanto fenômeno do outro, do ausente e que ela comumente exclui.

É sabido que a tradição teatral ocidental costuma delimitar a apresentação teatral ao "aqui e agora". E também na chamada época das mídias colocou-se um foco em "liveness", aura, efeitos de presença e o postulado de uma "copresença física". Atrás disso encontra-se uma concepção de imagem que devemos chamar de clássica. Ela diferencia de modo programático entre imagens teatrais (imagens que se surgem na performance teatral no aqui e agora de uma apresentação) e imagens geradas por mídias tecnológicas ou eletrônicas. Consequentemente, cria-se um concorrência entre 
imagens de filme ou vídeo e a visibilidade do ou no teatro.

Entretanto, nesse contexto discute-se cada vez mais a observação de que o surgimento das mídias digitais na virada para o século XXI mudou a ontologia das imagens, ou - para usar uma terminologia de William J. T. Mitchell que remete à fenomenologia - mudou o "estar-no-mundo" das imagens (Mitchell, 2007, p.243). Não se trata unicamente da questão, já muito lamentada, da inflação das imagens fotográficas, dos filmes e vídeos, ou de seu caráter de simulação, mas sobretudo de suas capacidades de acelerar a "circulação e disseminação" (Mitchell, 2007, 245) por meio das redes eletrônicas de internet e telecomunicação. Como imagens no fundo ausentes, elas estão permanentemente disponíveis e portanto presentes no horizonte de imaginação.

Os trabalhos de Hotel Pro Forma se destacam por colocar em jogo no teatro através de meios técnicos atuais e cenograficamente essas outras qualidades das imagens, qualidades de presença-ausência, criando "imagens de luz" nas quais pode aparecer o que é imaginado, recordado, no fundo irrepresentável ou de qualquer modo distante. Isso vale para a produção Operação: Orfeu, que guia o olhar de certo modo para o reino dos mortos, como também de outro modo para o projeto Algebra of Place. A abordagem experimental deste consiste em desviar o olhar de seu foco teatral habitual do "aqui e agora" para um lugar geograficamente distante, uma outra cultura e nesse sentido para um "outro lugar".

Já o título é programático: o significado original da palavra árabe "al-jebr" quer dizer junção, ligação. Conforme com isso, Algebra of Place é concebido como um diálogo visual entre Europa e o Oriente Médio, entre Ocidente e Oriente. Também este trabalho pode ser descrita como um "trançado cenográfico" - nesse caso de concepção intercultural - que se revela em sua referência específica a outros modos de narrar, outras tradições de ver, outros códigos visuais e mídias.

O projeto partiu de uma pesquisa de imagens. Na pré-produção, a equipe viajou para os Emirados Árabes, a Dubai, Abu Dhabi, Sharjah e o Omam, para captar com a câmera digital lugares icônicos bem como cenas cotidianas da outra cultura. De volta em Copenhague, procurou-se um contexto local adequado para o projeto. A escolha foi o Axelborg, um prédio comercial construído nos anos 20 do século $X X$, perto da estação central de trens, bem no centro da cidade. Que tem de especial uma arquitetura com um grande vão redondo interno. Em todos os andares existe uma estrutura de rotundas internas abertas em forma oval, encimada por uma cúpula. Podemos dizer que o prédio representa iconograficamente o legado da tradição arquitetônica europeia.

Dehlholm instalou no chão do térreo uma área de projeção horizontal circular. Havia uma outra área de projeção vertical que podia girar e parar em três posições diferentes. Nas balaustradas encontraram-se montados quatro projetores que podiam projetar de diferentes ângulos imagens alternantes. Essas imagens, que ao mesmo tempo eram as únicas fontes de luz, se direcionaram não apenas para as referidas áreas como tampouco foram limitadas por elas. Antes, criou-se a impressão que a narração visual da viagem à Arábia foi quase que desdobrada espacialmente para entrar em uma relação caleidoscópica cheia de tensões com o prédio local. 


\section{Urrdimento}

Luz Criativa - o legado de Appia e as cenografias intermidiáticas de Hotel Pro Forma

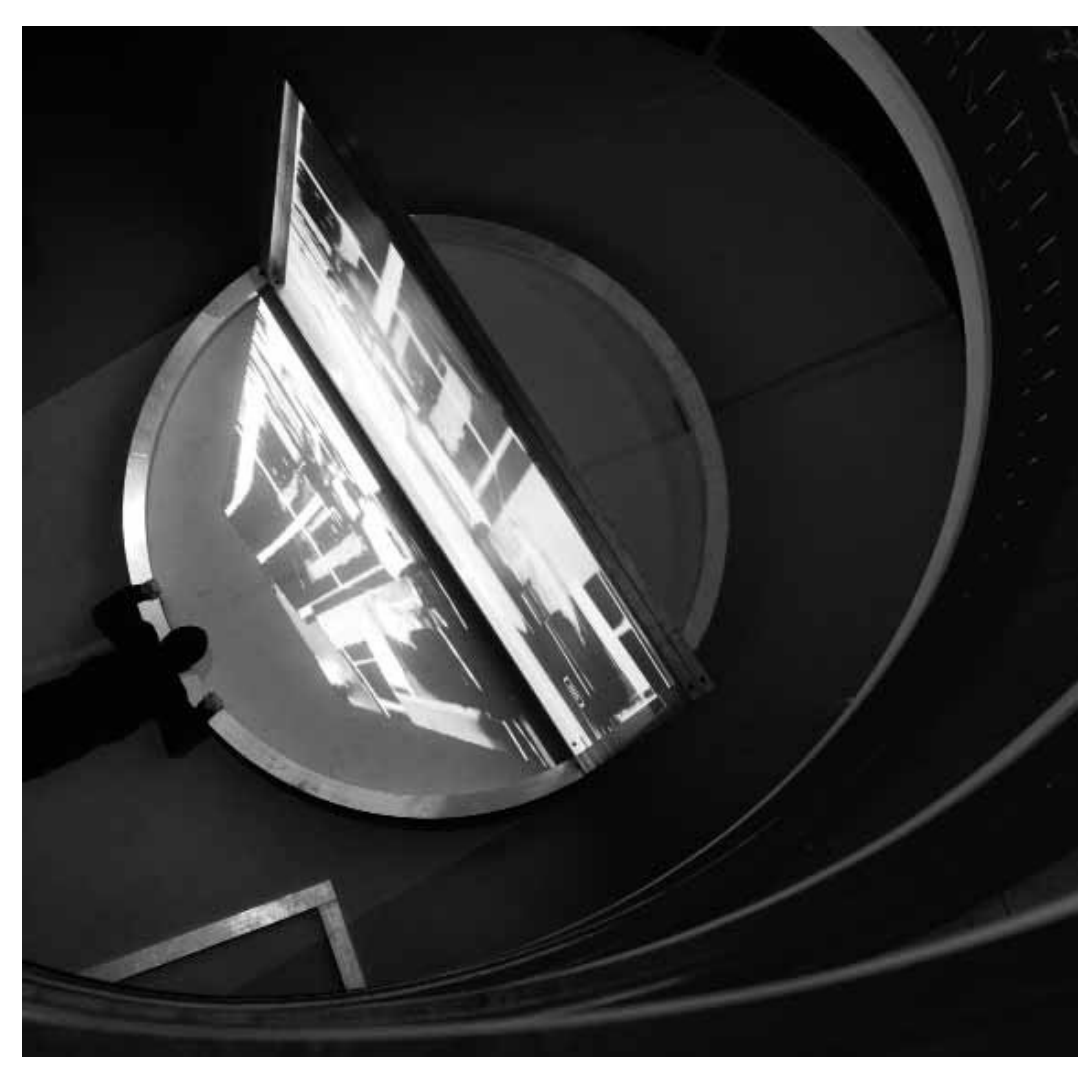

Imagem 5 - Cena de Algebra of Place

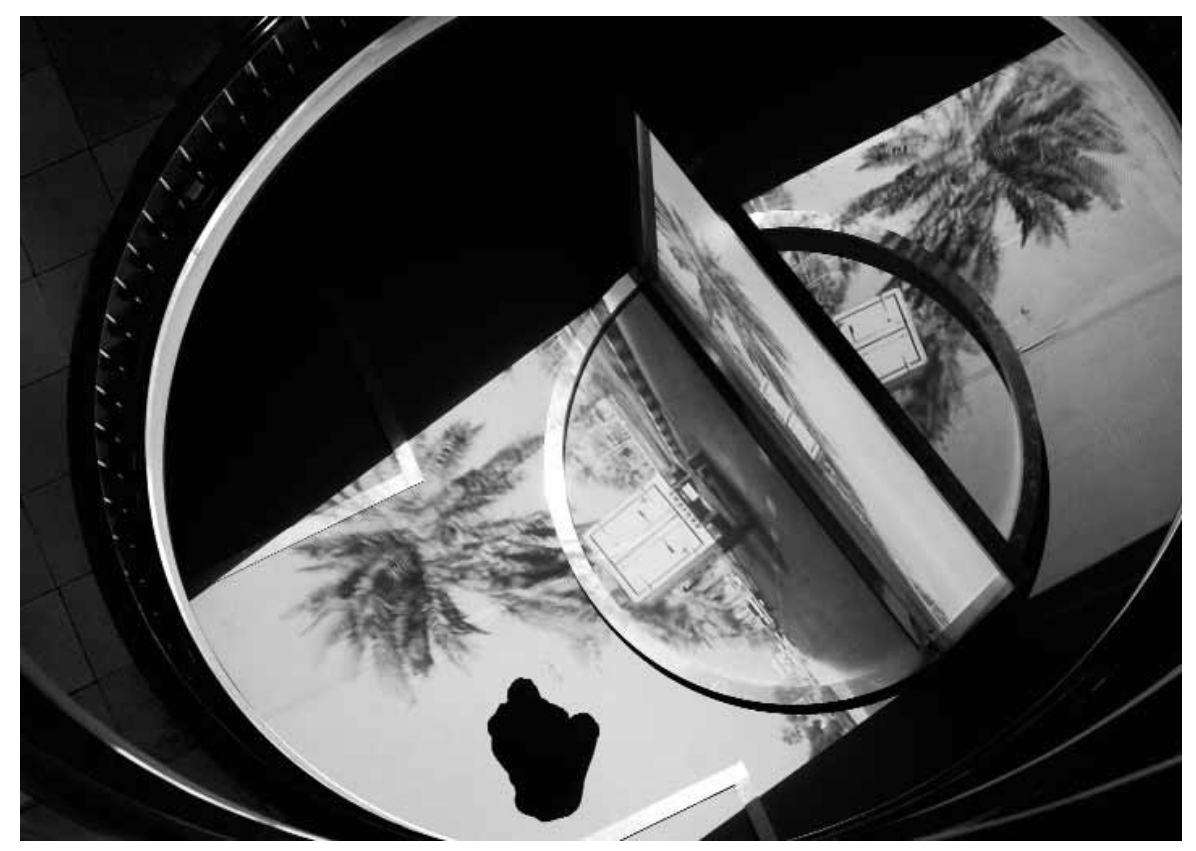

Imagem 6 - Cena de Algebra of Place 

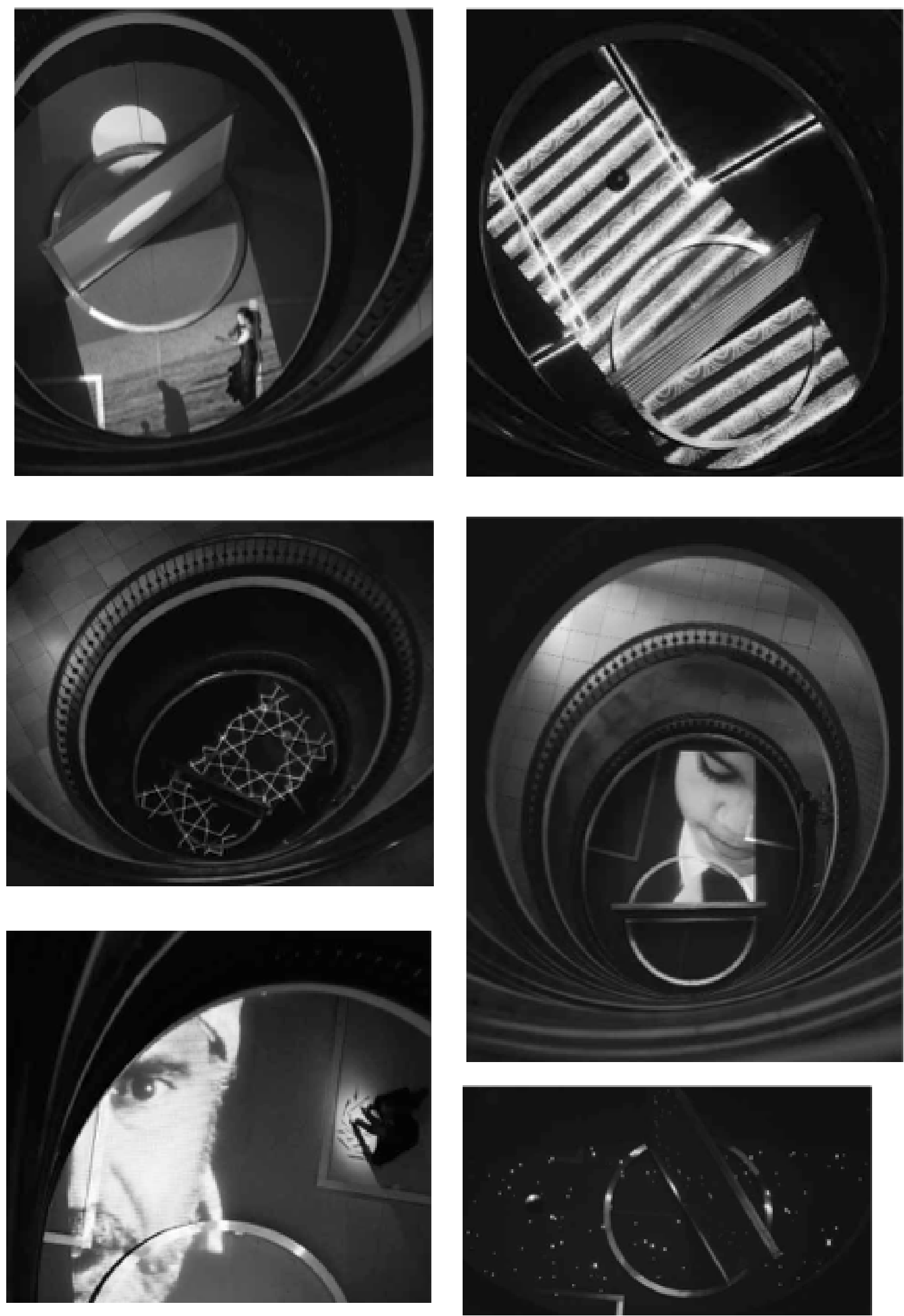

Imagem 7 a 12 - Cenas de Algebra of Place 


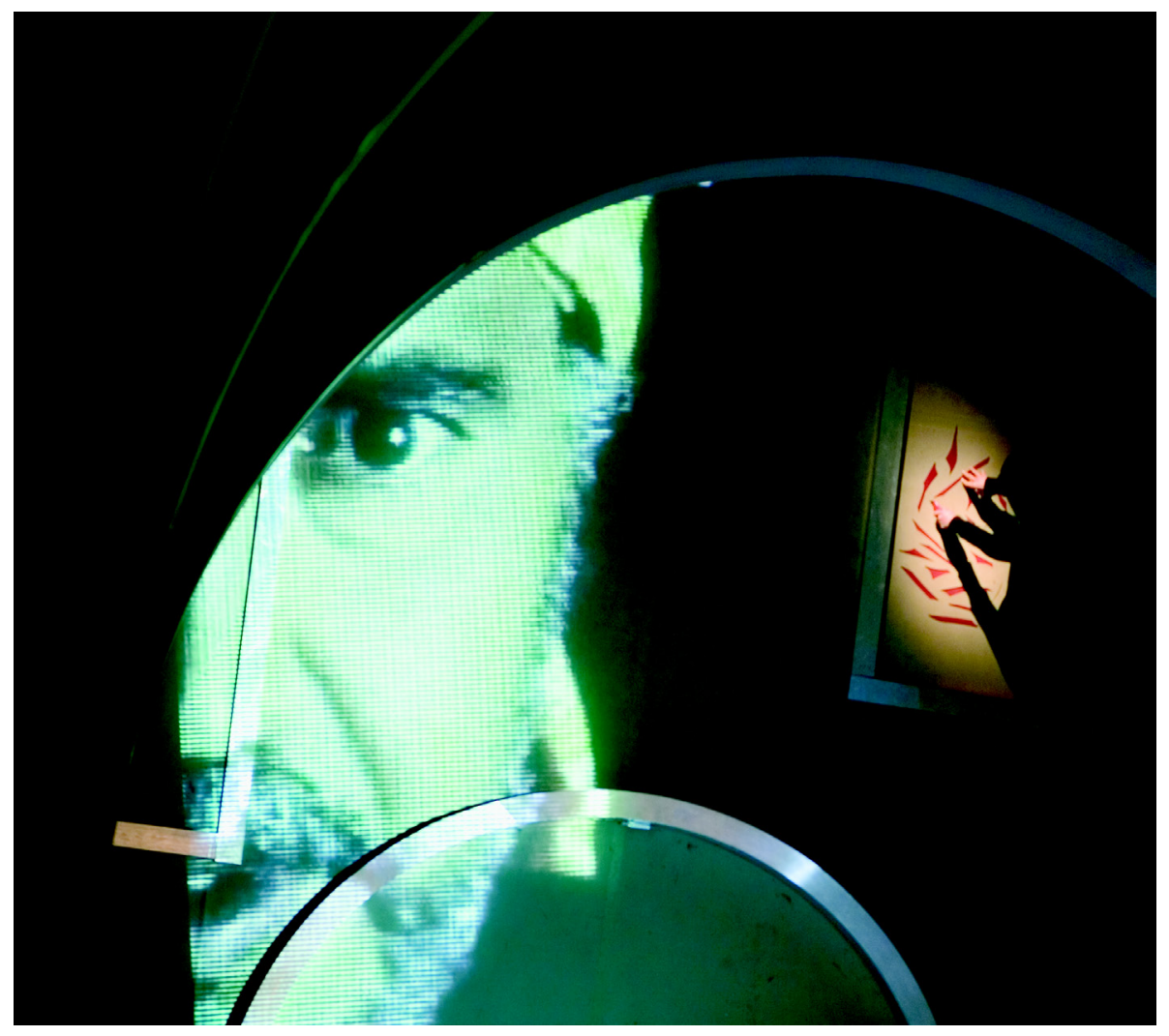

Imagem 13 - Cena de Algebra of Place

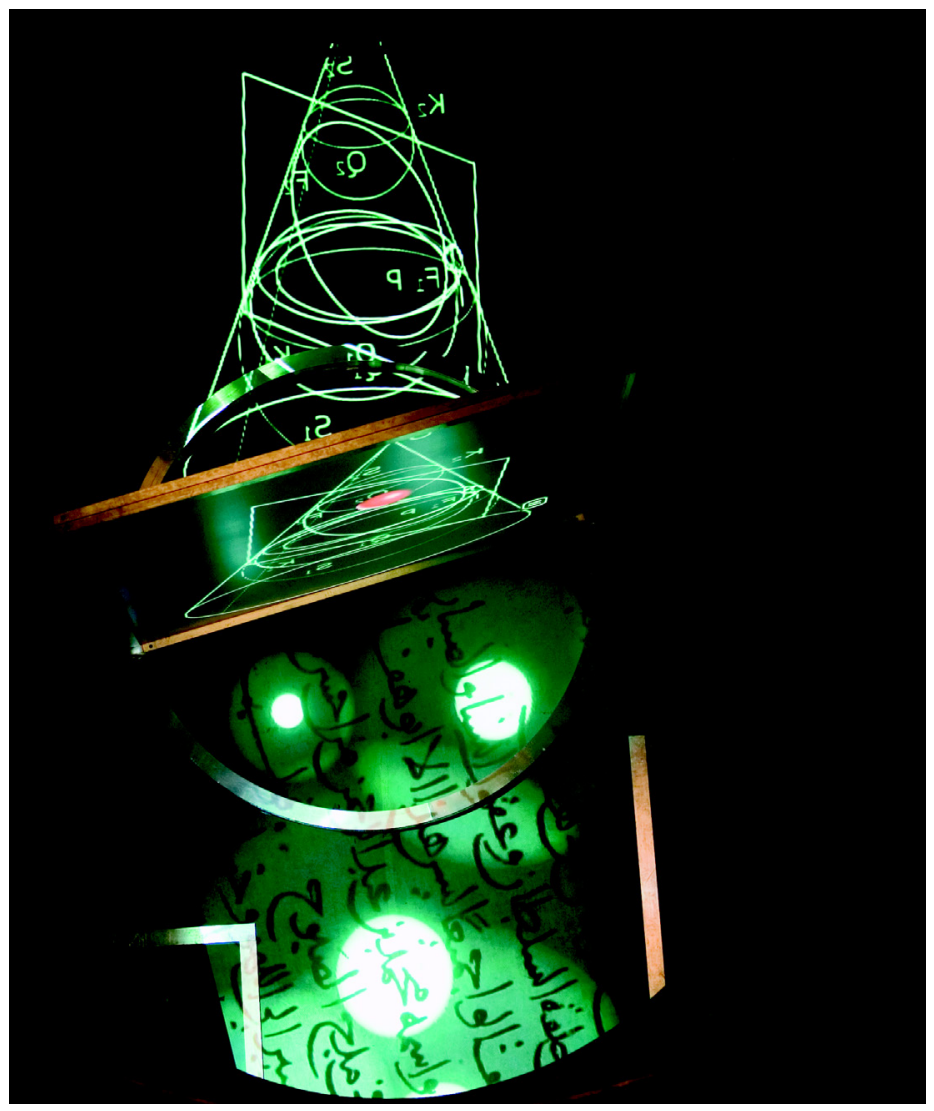

Imagem 14 - Cena de Algebra of Place 
Dramaturgicamente falando, o encontro entre as duas culturas foi concebido como um "caminho" por um hotel arábico virtual: após ouvir as boas vindas na hall de entrada, o público de Copenhague podia distribuir-se nos diferentes andares (e se quiser perambular, trocar de lugar e andar a qualquer momento); se desejar, nos andares inferiores podia-se mergulhar fisicamente nas ações, projeções e sons, ou acompanha - los dos andares mais de cima: uma viagem não-linear cheia de diversas vistas, como numa olhada por um caleidoscópio.

Uma performer, que alternadamente ficou presente fisicamente, ao se movimentar como se passasse por meio da projeção de filmes, ou virtualmente por estar dentro dos cenários filmados, teve a função de narradora e guia que levava o público - transeunte, no sentido como descrito - pelos diferentes cômodos, entre eles o "Gift Shop" [loja de presentes], o "Club Room" [salão de reuniões], a varanda e um "Learning Center" [centro de aprendizagem] para mística e saberes tradicionais. Nessa apresentação caleidoscópica de imagens, as diferentes estações não foram ilustradas e muito menos apresentados conforme a lógica da imagem perspectivizada. Antes, elas se comunicaram como uma Gestalt espacial dinâmica esférica, gerada por projeções e luz. Isso foi adensado ainda atmosfericamente por uma mixagem acústica ao vivo, cujo repertório passou da música árabe tradicional até cover versões de canções de Madonna. Em nível visual e também sonoro e impregnado por uma tradição árabe de narração que implica não um, mas muitos pontos de vista, apresentou-se, de fato, um "teatro sem ponto de fuga".

Um arabesco cinematográfico.

Um hotel árabe imaginário sem pontos de fuga.

Uma história na tradição da narrativa árabe com muitas vozes e várias verdades.

$\mathrm{Na}$ superfície ornamental da caixa de jóias ou da caixa de segurança da realidade.

Uma performance faz o check-in num hotel internacional num país árabe.

A música serve como guia de viagem.

É aqui que encontramos a mulher.

Será que ela é a narradora ou é aquela da qual ouvimos falar? ${ }^{9}$

(Hotel Pro Forma, 2006)

O projeto não remete ao código ocidental da perspectiva, mas ao código visual do arabesco e o afirma como o princípio de sua construção formal e da organização do olhar. Assim, apresenta uma visualidade que se formula como troca de olhares entre duas culturas e suas respectivas tradições visuais. Embora a história da arte e da cultura no ocidente conheça o arabesco como forma ornamental e decorativa sob o termo de "estilo nodular", baseado na geometria abstrata e apresentando ramagens e folhas trançadas ornamentais, não lhe foi atribuído um lugar na arte, mas no contexto do artesanato. Mais tarde, no decorrer do processo da auto-reflexão nas artes desde o século XIX, o arabesco foi redescoberto nas artes visuais e literárias enquanto "estranho" princípio formal alternativo. Além disso, entrou na composição musical e na dança (ver

9 A cinematique arabesque./ An imaginary Arabian hotel without vanishing points./ A story in the tradition of Arabian narration with many voices and several truths./ In the ornamental surface from the jewel case or safe-deposit box of reality./ A performance checks into an international hotel in an Arab country./ The music serves as travel guide/ This is where we meet the woman./ Is she the storyteller or is she the one we are told about? 
Jeschke/Wortelkamp/Vettermann, 2005).

O projeto Algebra of Place de Hotel Pro Forma atualiza o arabesco como princípio da organização visual. Compõe as imagens trazidas de um lugar longe no trançado arabesco das imagens cinematográficas e da visualidade da arquitetura e da performance no local da apresentação. O peculiar do arabesco consiste no fato de que, diferente da perspectiva que separa imagem e observador e atribui ao sujeito um lugar fora da imagem ou frente a ela, o arabesco traz o observador para dentro da qualidade espacial de sua visualidade como um sujeito receptor ativo. Esse projeto de Hotel Pro Forma recupera o arabesco como princípio visual multifocal, contra o princípio monofocal da perspectiva que, como técnica cultural de representação e apresentação profundamente enraizada na consciência ocidental, espalhou-se globalmente com a invenção da fotografia e mais uma vez com o surgimento das mídias eletrônicas (e suas arquiteturas de telas e janelas ['windows']). Como afirmou Hartmut Winkler, "nem a arte do Egito nem a arte de Roma antiga; nem a pintura medieval nem a iconografia cristã do Leste Europeu; nem a arte chinesa e nem a arte japonesa [usaram ou conheceram] modos de representação comparáveis à perspectiva" (Winkler, 1992, p.103). Também na Europa, ou seja, numa parte geograficamente bem limitada do mundo, ela domina a arte apenas durante poucos séculos, "de modo que em última instância foram as imagens tecnicamente produzidas que estabeleceram a perspectiva ao redor do globo" (Winkler, 1992, p. 103).

Por tanto, diferenças em relação a tradições de visualidade e do olhar, que caracterizam as diferentes culturas em seus estruturas profundas apesar da "avalanche de imagens" globais, devem ser analisadas por uma arqueologia das mídias. Como mostrou Hans Belting, com essa abordagem revela-se um surpreendente parentesco entre a cultura oriental e a cultura ocidental, se concedemos que foi o conhecimento de matemáticos e astrônomos árabes que marcou em grande medida o Ocidente em seus fundamentos reflexivos. Belting mencionou como especialmente importante o erudito Ibn al-Haitham, chamado de Alhazen, que realizou no século XI estudos para uma teoria do olhar. Num tratado posteriormente lido no Ocidente que contribuiu pra a "descoberta da perspectiva", Alhazen, baseado em cálculos matemáticos e experimentos óticos, estabeleceu um sistema geométrico de luz e feixes visuais que correspondia perfeitamente à espiritualidade abstrata das culturas árabes (ver Belting, 2008, p.104114). Também foi desenvolvida durante a sua vida a forma visual da "mashrabiyya", que Belting interpreta e valoriza como o equivalente árabe à "fenestra aperta" de Alberti, o conceito visual ocidental da imagem enquanto janela aberta (Belting, 2008, p.272-273).

Diferente das imagens ocidentais, as imagens da cultura árabe correspondem não a uma "geometria representacional", mas a uma "geometria representada" que joga com a luz como se organizasse a luz numa "imagem não-visual" que nas aparições mutantes da luz não se vincula à superfície plana, mas que se apresenta como fenômeno dinâmico e espacial.

Uma das cenas em Algebra of Place, a estação no "Learning Centre" faz alusão tanto às diferenças quanto aos pontos históricos de contato entre as duas culturas. $A$ descrita troca de olhares que o projeto executa trata não apenas de explorar (e respectivamente desconstruir) concepções ocidentais da imagem e da visualidade com meios cenográficos. Trata-se sobretudo de uma tentativa, em tempos marcados por 
fundamentalismo e xenofobia, de torna-las reconhecíveis em sua qualidade cultural particular e de inseri-las num diálogo intercultural construtivo. No caso de Hotel Pro Forma, o caminho para fazer isso passa por uma discussão da "luz criativa" e sobretudo por uma (re-) descoberta da luz oriental.

\section{3. "É tudo sobre possuir olhos para o mundo" - Considerações finais e olhada para frente}

"Em sua reflexão colorida encontramos a vida," diz Goethe. O teatro 'configura uma cena' para a vida, torna essa vida visual e acusticamente perceptível. Norteiam essa produção de imagens e de visualidade as ordens do olhar válidas nas respectivas culturas. Como indicado, elas variam em termos históricos e também geográficos, bem como os posicionamentos e modos perceptivos assumidos pelo observador em relação ás imagens.

A luz faz com que imagens virem acontecimento. Nesse sentido, desempenha um papel importante em todas as culturas. Como expliquei, a própria luz passa por interpretações que diferem culturalmente (sobretudo entre as religiões), como demonstra uma comparação da metafísica da luz islâmica ou budista com a judaico-cristã ou neoplatônica. Embora o iluminismo europeu secularizasse a luz, mantinha-se essa conotação também em nossa cultura. Ressoa, por exemplo, quando Martin Buber - ele mesmo um judeu - celebra a luz de Hellerau como luz criativa ou "criadora". O equipamento de iluminação espetacular de Hellerau marca uma virada em vários sentidos. Se o teatro, até então, posicionou os espectadores frente à imagem (gerada pelo palco ilusionista à italiano), agora acontece uma abertura e até uma democratização do espaço para qual contribuiu decisivamente a 'nova' luz. Desse ponto de vista, a invenção da eletricidade na modernidade e as inovações das mídias eletrônica na virada para o século XXI são o estopim de deslocamentos notáveis: põem as imagens em movimento; fazem com que se tornem por assim dizer 'nômades' para além das fronteiras culturais e as fazem aparecer literalmente sob outra luz.

A imagem cenográfica da tradição burguesa europeia está sendo, por assim dizer, sobrepintada por fenômenos de uma cenografia intermidiática que se estendem no espaço. A luz que é por sua vez efémera, sem lugar fixo e sem corpo, pode criar atmosferas e fazer com que imagens e corpos ganhem outro 'estar-no-mundo'. Como mostrei com os exemplos das duas produções de Hotel Pro Forma, o papel da luz não se limita à uma função apoiadora. Antes, a própria luz se torna uma força propulsora que, em primeiro lugar, cria a visualidade específica de uma apresentação cênica e determina a maneira de olhar de modo cada vez novo e diferente. $O$ fato de que a luz - mesmo na época das redes eletrônicas, das mídias digitais e da globalização - não existe livre de conotações culturalmente específicas e por tanto espirituais, ficou claro no último exemplo com sua investigação das formas da 'luz árabe'.

Se a luz 'criativa' é nesse sentido uma força propulsora, um meio da concretização cenográfica e de uma investigação para além das fronteiras culturais, sua contínua exploração pode oferecer uma oportunidade de abrir e transgredir interculturalmente o legado do palco italiano e da cenografia enraizado profundamente na história do teatro europeu, em favor de uma perspectiva e possibilidades totalmente diferentes de 
configurar uma imagem do mundo e de olhar para ele.

\section{Referências}

APPIA, Adolphe. "Die Musik und die Inszenierung", (1899). In: BEACHAM, 2006, p.70-107.

APPIA, Adolphe. "Darsteller, Raum, Licht, Malerei” (1954) In: LAZAROWICZ/ BALME, 1991, p.437-442.

BALME, Christopher. "Szenographie". In: FISCHER-LICHTE et al. 2005, p.322-325.

BEACHAM, Richard C. Adolphe Appia. Künstler und Visionär des Modernen Theaters. Berlin: Alexander, 2006.

BELTING, Hans (ed.). Bilderfragen. Die Bildwissenschaften im Aufbruch. München: Wilhelm Fink, 2007.

Blicks. München: C.H.Beck., 2008.

Florenz und Bagdad. Eine westöstliche Geschichte des

BOEHM, Gottfried (ed.) Was ist ein Bild? München: Wilhelm Fink, 2006.

BUBER, Martin. "Das Raumproblem der Bühne" (1913). In: LAZAROWICZ/ BALME, 1991, p.428-433.

DEHLHOLM, Kirsten. "Investigations of the World" in: THEIL, DEHLHOLM, QVORRUP, FORTUNA, 2003, p.99-119.

DÜNNE, Jörg, GÜNZEL, Stephan (eds.) Raumtheorie. Frankfurt: Suhrkamp, 2006.

FISCHER-LICHTE, Erika; KOLLESCH, Doris; WARSTAT, Matthias (eds.). Metzler Lexikon Theatertheorie. Stuttgart: Metzler, 2005, p.322-325.

FOUCAULT, Michel. La Pensée du dehors. Montpellier: Fata Morgana, 1986.

Die Ordnung der Dinge. Eine Archäologie der Humanwissenschaften. Frankfurt: Suhrkamp, 1989.

HERRMANN, Max. "Das theatralische Raumerlebnis." In: DÜNNE e GÜNZEL, 2006, p.501-513.

HOTEL PRO FORMA. Algebra of Place. Programa, 2006.

JESCHKE, Claudia; WORTELKAMP, Isa; VETTERMANN, Gabi. “Arabesken. Modelle 
'fremder' Körperlichkeit in Tanztheorie und Inszenierung." In JESCHKE/ZEDELMAIER, 2005, p.169-210.

JESCHKE, Claudia; ZEDELMAIER, Helmut (eds.). Andere Körper - Fremde Bewegungen. Theatrale und öffentliche Inszenierungen im 19. Jahrhundert. Münster: LIT, 2005.

KRÜGER, Klaus. “Das Bild als Palimpsest”, in BELTING, 2007, p.133-163.

LACAN, Jacques. Die vier Grundbegriffe der Psychoanalyse. Das Seminar: Buch XI. Weinheim/Berlin: Quadriga, 1987.

LAZAROWICZ, Klaus; BALME, Christopher (eds.) Texte zur Theorie des Theaters. Stuttgart: Reclam, 1991.

LEHMANN, Hans-Thies. Postdramatisches Theater. Frankfurt: Verlag der Autoren, 2005.

LINDERS, Jan. "Eine vollständige Theatersprache. Robert Wilson über Appia, Licht und Theater" in BEACHAM, 2006, p.7-10.

LYLE, Massey (ed.). The treatise on Perspective. New Haven/London: Yale University Press, 2003.

MERLEAU-PONTY, Maurice. Das Sichtbare und das Unsichtbare. Trad. Regula Giuliani e Bernhard Waldenfels. München: Wilhelm Fink 1994.

“Der Zweifel Cezannes”, in BOEHM, 2006, p.39-59.

MICHAEL, Ib. "Operação: Orfeu. Libretto" acessivel em http://www.hotelproforma.dk/UserFiles/File/Libretto_ENG.pdf. Acesso em: 24 de setembro de 2014.

MITCHELL, William. “Realismus im digitalen Bild” in BELTING, 2007, p.237-255.

NIETZSCHE, Friedrich. Die fröhliche Wissenschaft (1882). Stuttgart: Reclam, 2000.

PAVIS, Patrice. Dictionnaire du Théâtre. Paris: Dunod.

RÖTTGER, Kati; JACKOB, Alexander (ed.). Theater und Bild. Inszenierungen des Sehens. Bielefeld: transcript, 2009.

ROSENFELD, Myra Nan. "From Bologna to Venice to Paris. The Evolution and Publication of Sabastiano Serlio's Books I and II. 'On Geometry' and 'On Perspective', for Architects." In LYLE, 2003, p. 281-321.

SINCLAIR, Upton. World's End. New York: The Literary Guild of America, 1940. 
THEIL, Per; DEHLHOLM, Kirsten; QVORRUP, Lars; FORTUNA, Roberto (eds.) Hotel Pro Forma. The Double Staging: Space and Performance. Kobenhagen: The Danish Architectural Press, 2003.

WINKLER, Hartmut. Der filmische Raum und der Zuschauer. Heidelberg: Carl Winter, 1992.

Recebido em: 20/09/2014

Aprovado em: 22/09/2014 